\title{
Investment under company- level pacts before and during the Great Recession
}

Economic and Industrial Democracy 2015, Vol. 36(3) 50I-522

(c) The Author(s) 2013

Reprints and permissions: sagepub.co.uk/journalsPermissions.nav DOI: $10.1|77 / 0| 4383|X| 35 \mid 1999$

eid.sagepub.com

@SAGE

\section{Lutz Bellmann}

Institute for Employment Research, Germany

\author{
Hans-Dieter Gerner \\ Institute for Employment Research, Germany
}

\section{Olaf Hübler}

University of Hannover, Germany

\begin{abstract}
Company-level pacts between the management and the works council are often preferred in comparison to agreements between employers' association and unions because the former negotiating partners are better informed about the economic situation of a company and have fewer goal conflicts than the latter. Moreover, these company-level pacts might reduce the "holdup' problems which arise once specialized investment is made. Therefore, this article investigates whether such agreements affect firm-level investment. Based on the IAB Establishment Panel Survey 200I-2010 the study indicates that the adoption of a company-level pact leads to a higher investment rate than in other firms driven by reinvestment. However, the Great Recession has damped this positive influence. From the econometric analysis the article does not detect any increase in investment during the negotiation phase. After the expiration of a company-level pact, lower reinvestment and a small increase in net investment take place.
\end{abstract}

\section{Keywords}

Deregulation of industrial relations, industrial relations, trade unions

It is widely acknowledged that German reforms of the past decade have been designed with competitiveness and employment in mind; thereby the low wage increases have had a material effect on export competitiveness in a range of manufacturing industries, such as industrial machinery. (Spence and Hlatshwayo, 2011: 37)

\section{Corresponding author:}

Hans-Dieter Gerner, Institute for Employment Research, Regensburger Str. 104, Nuremberg, 90478,

Germany.

Email: hans-dieter.gerner@iab.de 


\section{Introduction}

In the old days, the German bargaining system, in principle, recognized only two players, employers' associations and trade unions. These two players negotiated wages and working conditions, such as working time, holidays, etc. and these negotiations resulted in collective bargaining agreements that defined the standards for the majority of the employees. An exception to this bargaining system at the industry level were large-scale enterprises, which directly concluded a (firm-level) bargaining agreement with the trade unions. Since the middle of the 1980s, there has been an increasing demand for more flexibility in the German bargaining system. Due to the introduction of opening clauses into the collective as well as the firm-level bargaining contracts, representatives of establishments and workers often have the authority to agree upon deviations from the standards defined in the basic agreements if some triggering event occurs. Such an event might be a bad economic situation or strong competitive pressure. The application of an opening clause usually becomes contractual within a company-level pact (CLP). In practice, trade unions have to agree on the application, i.e. they have to decide whether the triggering event indeed occurred and whether the magnitude of the deviations is justified.

From an employer's perspective, CLPs are completed to reduce wages or, more generally, labour costs, and as a consequence thereof, to reduce prizes or increase available funds to finance investments that are necessary for maintaining competitiveness or avoiding economic problems. Although it is, a priori, not obvious whether labour costs induce economic problems or whether reducing labour costs is an adequate strategy, many establishments try to minimize such costs by adopting company-specific deviations based on an industry-level wage contract. In fact, in recent years, we have observed a tendency towards more local bargaining and flexibility in the negotiations of opening clauses and CLPs for employment and competitiveness in Germany as different types of CLPs have been observed. On the one hand, agreements exist that are characterized by company-specific deviations in an industry-level contract regarding the acceptance of reduced wages. On the other hand, there are CLPs that are implemented or stipulated in establishments without collective contracts or that allow collective agreements to go unaltered. A deal regarding work hours, a stipulation about increased flexibility or an agreement regarding modernization of capital stock are typical elements of CLPs. Moreover, these contracts are associated with safeguarding firm locations in accordance with the firm's global sourcing and production strategies. Increasingly, companies promise not only measures to stabilize employment but also ways to improve the firm's competitiveness through investment programmes.

Previous empirical investigations regarding CLPs have focused on the impact of such agreements on employment, training and economic positions of firms. Until now, however, detailed investigations about the effects of CLPs on investments have been absent.

This article seeks to fill the research gap and applies econometric methods to study firm investment decisions at the level of the individual plant. Using the IAB Establishment Panel Survey, we investigate heterogeneity in behaviour between different types of plants. Structural information about the establishments, beginning with information about the establishments before the CLPs were finalized, is necessary to evaluate the impact of CLPs. These data are provided by the IAB Establishment Panel Survey. 
Our major intention is to analyse the investment activities of establishments with CLPs in comparison to the investment activities of establishments without these pacts. Empirically, we intend to show under what conditions CLPs induce higher investments and under what conditions they induce lower investments than establishments without CLPs. This overall objective is split into secondary aims, and the following questions are investigated. Are there differences between replacement investments and net investments of these two groups of establishments? Are there higher fundamental reductions in investment activities during the great international crisis of 2009 compared to the precrisis period? Does the firm investment behaviour differ during negotiations from that during and after the contract period of the CLPs? From a theoretical perspective, there is not a unique hypothesis regarding investment effects of CLPs. We find different channels of explanation, and the results are partially contradictory, as demonstrated in the short literature review presented in the next section. Further, as the role of the financial crisis is not unambiguous, the outcome is not known in advance. Accordingly, the empirical investigation is conducted without any fixed expectations regarding the results.

The article is structured as follows. The second section provides a short overview of the related literature. The third section describes the IAB Establishment Panel Survey data and discusses methodological issues. The fourth presents empirical results. The fifth section concludes the article.

\section{Literature related to company investments, industrial relations and company-level pacts}

\section{Business investment and industrial relations}

Traditional investment functions are generally modelled with respect to classical and accelerator theories. Profits and changes in demand are the major determinants and the estimates are based on aggregated data. However, during the last 20 years, economists' focus has shifted to the analysis of investment at the firm level. Many studies on firmlevel investment are based on the standard accelerator specification. A good example is Mairesse et al. (1999).

The impact of the union representation of employees on firm investment is considered in several studies. From a theoretical point of view, unions may exert a negative as well as a positive impact on firm investment. In a traditional model, unions exogenously set wages and may or may not propel firms to substitute capital for expensive labour (Addison et al., 2007). Thereby, the degree of substitutability between capital and labour, as well as the effect of union representation on output prices, determine the ultimate effect on investment. If unions seek to expropriate quasi-rents, which arise once investment in specialized plant equipment has been made, the firms are confronted with a 'hold-up' problem. Therefore, a strong presumption in the literature on this topic is that greater worker representation will depress investments in capital, because firms anticipate the 'hold-up' problem. For example, Bronars and Deere (1993) estimate a negative effect of unionization on investment, but the empirical significance of hold-up effects in the labour market is unclear. Existing studies suggest that wages respond to employer-specific gains in productivity (e.g. Guertzgen, 2010). Card et al. (2011) argue that hold-up depends on whether 
the wage bargaining process allows the firm to recoup its investment costs before splitting the rents with employees, and not on rent-sharing per se.

Freeman and Lazear (1995) argue that a works council acts as a communicator between management and workers, and thus the likelihood of a 'hold-up' problem might be reduced. This argument is especially true if the management and the works council successfully negotiate a CLP. Thereby, the firms' investment incentives are increased. In contrast, an economic crisis tends to decrease the investment incentives because it deteriorates business expectations. In addition, strategies to cut wage costs can be regarded as a prerequisite for enhancing the firm's ability to finance investment projects. Empirical studies on the effect of works councils do not provide a clear picture. The impact on innovation and investment is ambiguous. Addison et al. (2001, 2007) and Jirjahn (1998) cannot find proof of significant effects of the existence of a works council on process and product innovation. If the works council is not modelled as an exogenous variable but is instead instrumented as the probability of product but not of process innovation, then product innovation is significantly higher in establishments with councils (Addison et al., 1996). In middle-sized firms with 100-300 employees, the effects of the works council on investment in the Old and New Economy are significantly positive in Germany, where the indirect effects via reorganization and training of the workforce are dominant compared to direct effects (Hübler, 2003). Investment in the environmental protection in establishments is also positively correlated with the existence of a council, if the council is led by employees rather than firm managers (Askildsen et al., 2006).

\section{Company-level pacts}

Several studies commissioned by the European Foundation for the Improvement of Living and Working Conditions review both the large number of social pacts at the sectoral and national level as well as those at the company level (Freyssinet and Seifert 2001; Sisson and Martin Artiles, 2000; Sisson et al., 1999; Zagelmeyer, 2000). Collective pacts for employment and competitiveness have been negotiated in many European countries at a national level based on a tripartite dialogue involving government, employer associations and trade union representatives. At the sectoral and company levels, such pacts have primarily been agreed upon by management and employee representatives. 'The PESs - company level pacts - are adding to the pressure for decentralisation of collective bargaining observed in Western Europe since 1980. Sometimes they have benefited from the decline of sector-level negotiation (as in the UK), and sometimes they have been made possible by the widening of the field of responsibility bestowed upon company negotiation (as in France, Italy and Netherlands). In other countries, they reflect the introduction of "opening clauses" or "hardship clauses" into sector agreements (as in Austria and Germany)' (Sisson, 2001: 606). In the United States and Canada, similar agreements have been negotiated through concession bargaining, which was a widespread practice in the 1980s (see e.g. Bell, 1995; Cappelli, 1985; Eaton and Verma, 2006). A major difference between CLPs in Germany and concession bargaining in North America is that contracts for CLPs are bilateral, meaning that not just employees abandon warranties. CLPs can be defined as give-and-take agreements. In the German tradition of company co-determination, reciprocal commitments 
are constitutive, and CLPs are more complex than a traditional firm's agreement and include issues that are beyond traditional co-determination. In practice, there exists a wide range of specific arrangements. The management's right to decide about investments can be limited, and personal and investment strategic decisions can be combined. Employers and employees both contribute their decision-making authority to the solution of a joint problem. Economic problems of an establishment, such as an acute crisis or a threatening loss of competitiveness, build the origins of CLPs.

In Germany, works councils can agree to company-specific pacts with management if there is no collective bargaining contract. However, the conventional case is a two-tier system whereby working conditions are negotiated at the industry level. The resulting industry-level bargaining contracts are binding in that management and works councils need the permission of the employer association and the trade union representatives if they agree on conditions that are less favourable for the employees than those stipulated in the relevant contract at the industry level. This means that, on the basis of the clauses and on the consensus of the respective union and employer association regarding the existence of an economic hardship or crisis, management and the works council must agree on the application of an opening clause and possibly stipulate to additional specific objectives. Therefore, in some cases, collective bargaining fulfils not only its traditional role of implementing legal provisions but also suggests that a crisis has been prevented or that the competitiveness has been improved. Collective bargaining is responsible for new tasks and responsibilities (Ellguth and Kohaut, 2008; Lesch, 2008) and works councils are involved in economic decision-making within the company (Sisson, 2001: 602).

With respect to working time, wages and work organization, management and works councils must agree on the conditions. The duration of a CLP must also be established. While it is possible that recorded CLPs are determined within the framework of specific company declarations or in employee labour contracts, it is also possible that only an oral acknowledgement serves as the basis of a CLP. As the formulations are not always exact, compliance with specific CLP agreements is not enforceable. In most cases, the consent is connected on the employer side to explicit pledges such as employment and location guarantees or investment programmes.

With respect to the contents of the contracts negotiated between management and works councils, a change in the importance of employment guarantees and investment programmes is observed. Massa-Wirth and Seifert (2004) report that while $71 \%$ of all agreements in 2003 contained clauses concerning the exclusion of layoffs initiated by the employer, only $20 \%$ of these agreements included employer pledges about investment programmes. In contrast, Bogedan et al. (2011) find that in $2009,50 \%$ of all agreements excluded company-initiated layoffs and that $54 \%$ of these agreements contained the company's pledge regarding investment programmes. These results suggest a conflict of interest within the CLPs between the goal to save jobs and to include investment programmes. Using data for the German mechanical engineering and electrical machinery industry sector in 2007, Lesch (2008) finds that employers' pledges were mainly in the field of employment $(75 \%)$, while investment guarantees were part of $34 \%$ of all agreements.

Agreements between management and the works councils are often preferred in comparison to those between employer associations and unions because the negotiating 
partners in management and works councils are better informed than those in employer associations and unions about the economic situation of a company and they are less likely to have conflicting goals regarding the outcomes of a negotiation. However, these pacts face a structural problem as employee concessions are made before employers are able to redeem the pledges that they (the employers) have made to employees. This is demonstrated by Bogedan et al. (2011) who find that in $29 \%$ of all cases, elements of the agreement are broken, but not necessarily solved. If the relations between the management and the works council are good, the probability of fulfilling the contract is greater, thereby increasing the works council's trust in management and vice versa (Hübler, 2005; Nienhüser and Hoßfeld, 2010a, 2010b). The medium- and long-term effects of CLPs on competitiveness are not under the employers' control. Rather, they depend on the respective sector and the company's overall market position within it, with prices and products being of special interest (as shown empirically by Sisson and Martin Artiles, 2000).

Usually, management alone decides whether and how much the firm will invest. However, under a CLP, the works council and employees are either directly or indirectly involved in the decision-making process. Some pacts agree explicitly on investments for a specific location, while others are silent on this issue or include only general agreements regarding the modernization or updating of a firm's capital stock. CLPs may provide a solution to the 'hold-up' problem as they prohibit unions from exploiting quasi-rents, which arise from firm-specific investments if wages are set simultaneously (or in conjunction) with investments. In the standard setting, under-investment arises because of the possibility of wage renegotiations by unions after the installation of sunk capital by the firm. However, with CLPs, often a binding agreement on wage moderation and other deviations from collective bargaining is signed before the installation of new capital.

As the main intentions of CLPs are to ensure employment stability and to improve firm competitiveness, employees abandon certain monetary and non-monetary warranties while the employer adopts measures to stabilize firm employment. The literature focuses on the employment effect of CLPs (Sisson and Martin Artiles, 2000). Despite the widespread incidence of CLPs in some economic sectors, the number of companies adopting CLPs is rather limited. Company case studies are presented by Zagelmeyer (2010).

A discussion regarding the problems and features of CLPs can be found in MassaWirth and Seifert (2005), Seifert and Massa-Wirth (2005) and Bogedan et al. (2011). A survey of work councils conducted by the Economic and Social Research Institute (WSI) explains the economic and institutional factors that influence the spread and composition of these concessionary agreements. Using data from the IAB Establishment Panel Survey 2004-2006, Ellguth and Kohaut (2008) investigate the probability that a CLP negotiation will be successful and determine that CLPs are more widespread if the profit situation is weak, if work time accounts and works councils exist, if the works councils are not hindered by the employer and if the establishments are large. The latter fact is in contrast to concession bargaining in North America. Bell (1995) has found that while small firms are more often engaged in concession bargaining, concessions are significantly less common in establishments with above-average performance, with low base wages or with relatively high union coverage rates. 
Econometric studies reveal various impacts of CLPs on employment (Bellmann and Gerner, 2012a; Bellmann et al., 2008; Hübler, 2005), on firm investments in additional training (Bellmann and Gerner, 2012b) and on the enterprises' economic situation (Hübler, 2006). Investigations show that a CLP has a better chance to be successful if the initiative is begun by the employer, if a CLP is incorporated during a strong economic period for the establishment and if a proper package of measures is agreed upon. While renegotiations initiated by works councils have improved results in some cases, no silver bullet for all firms can be identified or suggested as idiosyncrasies of the firm must be considered (Hübler, 2005, 2006). A study by Bogedan et al. (2011) reveals that the relationship between the works council and management can be regarded as the decisive factor regarding the stability of the CLP. If the works councils assess the contract to be fair and the contract contains agreements regarding the preservation of the number of employees, the employers will likely fulfil the pledges they made.

To summarize our survey of the related literature regarding company investment and CLPs and regarding studies conducted using data at the establishment level that consider the effect of employees' representation on a firm's investment incentives, the effects of employee representation on firm investment incentives are ambiguous. CLPs appear to be of special interest because it can be expected that CLPs reduce the 'hold-up' problem, which, in turn, decreases the firm investment incentives despite the empirical evidence regarding these agreements. The effect of the CLP on employment, on firm training and on the economic situation of a firm is rather limited and is not always positive. This observation holds even when controlling for the different types, phases and durations of CLPs.

Thus far, the effects of CLPs on investments had not been investigated from an econometric perspective.

\section{Data and methods}

\section{Data}

The German IAB Establishment Panel Survey of the Institute for Employment Research of the Federal Employment Agency (IAB) is a representative survey of German establishments employing one or more employees from the private sector, excluding agriculture, forestry and fishing, covered by social insurance. The panel started in 1993 with an annual survey of West German establishments and was extended to East Germany in 1996. Since 1996, more than 15,000 establishments have been included in the survey. The IAB Establishment Panel provides information on many labour market topics, including employment, wages, sales, bargaining levels, works councils, profit sharing and investments. Wave 2006 provides many details regarding CLPs including retrospective data. In following waves, it is also asked whether an establishment has a CLP, and, if so, when the pact was adopted. Furthermore, the duration of a pact is identified. We also know whether any negotiations on such arrangements currently persist, whether an agreement existed in the past and is now discontinued, and whether efforts to achieve such an agreement failed in the past.

Our investigation is focused on data for the period 2001-2009. Public sector establishments are excluded. The establishment-level capital stock is approximated by 
applying the modified perpetual inventory approach proposed by Mueller (2008) that combines the firm's i information from the IAB Establishment Panel with those of the industry's depreciation rate.

\section{The model and methods}

The starting point of our firm-level investment analysis is the approach of Mairesse et al. (1999) who develop an accelerator model of investment with error correction where an autoregressive-distributed lag of length two $\operatorname{ADL}(2,2))$ is assumed.

The LHS variable is the growth rate of capital stock as a function of both growth rates and levels information. The error correction term is the difference between the log of the capital and that of the sales in year $\mathrm{t}-2$. The investment ratio $\left(\mathrm{I}_{\mathrm{it}} / \mathrm{K}_{\mathrm{i}, \mathrm{t}-1}\right)$ is used as a proxy for the net growth rate of the capital stock where $I_{i t}$ is the investment in firm i for year $t$ and $\mathrm{K}_{\mathrm{i}, \mathrm{t}-1}$ is the capital stock at the end of year $\mathrm{t}-1$. The basic estimation equation is as follows:

$$
\Delta \mathrm{k}_{\mathrm{it}}=\delta_{0}+\delta_{1} \Delta \mathrm{k}_{\mathrm{i}, \mathrm{t}-1}+\delta_{2} \Delta \mathrm{s}_{\mathrm{it}}+\delta_{3} \Delta \mathrm{s}_{\mathrm{i}, \mathrm{t}-1}+\delta_{4}\left(\mathrm{k}_{\mathrm{i}, \mathrm{t}-2}-\mathrm{s}_{\mathrm{i}, \mathrm{t}-2}\right)+\delta_{5} \mathrm{~s}_{\mathrm{i}, \mathrm{t}-2}+\mathrm{u}_{\mathrm{it}},
$$

where $k_{i t}$ is the $\log$ of the capital stock, $s_{i t}$ is the log of the sales in firm i for year $t$ and $u_{i t}$ is the error term, $\delta_{1}$ measures the short-run and $\delta_{4}$ is the coefficient of the error correction term, the long-run effect. We start with OLS estimates. Instrumental variables estimates are then employed due to possible endogeneity, and several robustness checks are carried out - see Appendix Tables A3-A4.

Our main objective is to investigate whether CLPs foster or hinder investment activities. Hence, it is assumed that in the investment ratio equation (1) the absolute term $\delta_{0}$ is not fixed but is rather a function of the dummy variable CLP. Furthermore, we extend this function by investment determinants, namely, by sector dummies (SEC) and firmspecific characteristics. We control whether the firm follows an industry-wide central bargaining system (CB), has a works council (WOCO) and has adopted profit sharing (PS) so that

$$
\delta_{0 \mathrm{it}}=\delta_{00}+\delta_{01} \mathrm{CLP}_{\mathrm{it}}+\delta_{02} \mathrm{CB}_{\mathrm{it}}+\delta_{03} \mathrm{WOCO}_{\mathrm{it}}+\delta_{04} \mathrm{PS}_{\mathrm{it}}+\mathrm{SEC}_{\mathrm{it}} \delta
$$

These determinants are more or less time-invariant. If they are neglected, their influences are essentially components of unobserved firm fixed effects, although not completely, as changes are possible after some periods. Due to theoretical arguments and empirical results - see earlier - we expect $\delta_{02}<0$ and $\delta_{03}>0$. In firms with profit sharing, employees might hinder investments because the level of profits that can be shared with workers is lower if investment activities are high as investment costs reduce profits in the short-run. Kruse (1993: 49) expects the same effect from the viewpoint of employers. He argues, 'If employees collectively receive a predetermined fixed share of profits, they will naturally share in any increase in profits from new capital investments, thereby decreasing the return on profits for the firm's owners. This decreased return would decrease the incentives for investment.' From this perspective, 
Table I. Descriptive statistics of gross investment per capital 2006; number of observations, medians, means and standard deviations.

\begin{tabular}{lcccc}
\hline Establishment & Observations & Median & Mean & SD \\
\hline (I) Without CLP & 4594 & 0.1136 & 0.2348 & 0.3069 \\
(2) With CLP & 334 & 0.2067 & 0.2922 & 0.2921 \\
$\begin{array}{l}\text { (3) Planned CLP - } \\
\quad \text { negotiations for CLP }\end{array}$ & $4 I$ & 0.2014 & 0.2893 & 0.3058 \\
(4) CLP in the past & 79 & & & \\
(5) Planned but failed CLP & 45 & 0.1612 & 0.2584 & 0.3067 \\
\hline
\end{tabular}

Notes: The outliers of investment per capital (IPC) are eliminated, i.e. outside the $95 \%$ confidence interval. In other words, firms with IpC > I.33 are neglected assuming that these are measurement errors.

Source: IAB Establishment Panel, 2006.

$\delta_{04}$ should be negative. However, one can also argue that investments increase future profits, in which the employees participate. Therefore, employees have an incentive to support successful investments. Under this framework, it makes sense that a profit sharing scheme is installed in a CLP together with investment promises by the employer and wage or other concessions made by the employees. This suggests that the sign of $\delta_{04}$ depends on whether employees are more focused on the short- or long-run considerations of their decisions. Empirical investigations that do not consider CLPs often find only insignificant effects of profit sharing on investment (see e.g. Blanchflower, 1991; Jirjahn, 1998).

In a next step we analyse the 'phases of CLPs', i.e. the adoption of a CLP and when the CLP is expired. Moreover, the investment effects of CLPs are not only compared with those firms without any CLP but also with those of firms which negotiate over a CLP. The intention of such a comparison is to find out whether investment effects can be observed during the bargaining period. The comparison with firms that failed to install a CLP involves a similar objective. And finally, we compare with firms that had a CLP in the past which has since expired.

\section{Results}

\section{Descriptive statistics}

At first glance, the means in Table 1 seem to confirm this basic idea. Firms with a CLP have on average higher gross investments per capital than other firms. In addition, this table shows that establishments that have planned or negotiated over CLPs have lower investment ratios compared to those that adopted a pact. This phenomenon is also the case for establishments that adopted CLPs in the past.

It can be inferred that investment ratios increase at the beginning of a pact (compared to the pre-pact period) but fall again when the pact expired. The comparison between the medians and the means demonstrates that the distribution of gross investment per capital is positively skewed. The majority of the data are found bunched to the left with a long tail to the right. 


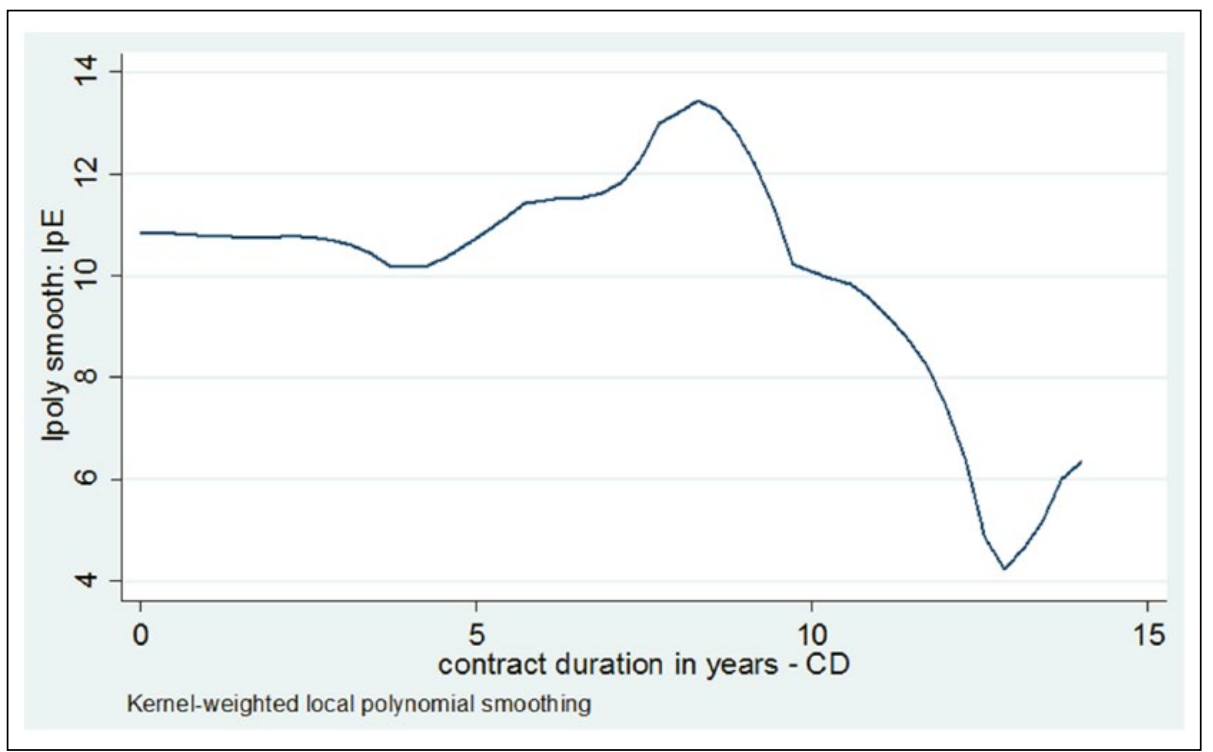

Figure I. Investment per employee (IPE) with respect to the duration of company-level pact (CD).

Source: IAB Establishment Panel.

The development of the investment per employee with respect to the duration of a CLP is depicted in Figure 1, where a kernel-weighted local polynomial smoothing approach is applied (Fan and Gijbels, 1996). The graph clearly shows that investments are slightly falling in the first phase of the CLP. Then, after approximately four years, we observe an increase in firm investment. The investment activities peak after roughly eight years, and then a sharp decline occurs. On average, the length of a company-level pact is 2.8 years with a standard deviation of 3.9 years. The frequency distribution of the length of a CLP in our sample is:

\begin{tabular}{llllllll}
\hline Number of years & 0 & I & 2 & 3 & 4 & 5 & $>5$ \\
\hline Number of firms & 306 & 624 & 419 & 248 & 131 & 82 & 234 \\
\hline
\end{tabular}

And that of the years of adopting a CLP is:

\begin{tabular}{lllllll}
$\begin{array}{l}\text { Years of } \\
\text { adopting a CLP }\end{array}$ & $<=1990$ & $1991-1999$ & $2000-2002$ & $2003-2004$ & $2005-2006$ & $2007-2008$ \\
\hline Number of firms & 24 & 131 & 149 & 426 & 964 & 350 \\
\hline
\end{tabular}


Table 2. OLS and IV estimates of CLP effects on investment rate - standard model.

\begin{tabular}{|c|c|c|c|c|c|c|}
\hline & \multicolumn{3}{|l|}{ OLS } & \multicolumn{3}{|l|}{ IV } \\
\hline & $N$ & Coef. & SE & $N$ & Coef. & SE \\
\hline \multicolumn{7}{|c|}{ Panel A: 200I-2009 } \\
\hline Total investment & 16,599 & 0.0424 & 0.0614 & 16,470 & 0.1341 & 0.3618 \\
\hline Reinvestment & 16,349 & 0.0625 & 0.0629 & 16,222 & 0.1192 & 0.2878 \\
\hline Net investment & 16,354 & $-0.0202 * *$ & 0.0083 & 16,222 & $-0.1316 * * *$ & 0.0445 \\
\hline \multicolumn{7}{|c|}{ Panel B: 200I-2008 } \\
\hline Total investment & 12,546 & 0.0996 & 0.0810 & 12,564 & 0.2298 & 0.4807 \\
\hline Reinvestment & 12,360 & 0.1179 & 0.0829 & 12,379 & 0.1381 & 0.2234 \\
\hline Net investment & 12,363 & -0.0156 & 0.0099 & 12,379 & $-0.1356 * * *$ & 0.0168 \\
\hline
\end{tabular}

Notes: * significant at the $10 \%$ level; ** significant at the $5 \%$ level; $* * *$ significant at the $1 \%$ level. For complete estimates of CLP effects on total investment of the standard model in Panel A, see Appendix Table A2.

Cluster robust standard errors with respect to the firms are presented. In the IV estimates CLP is instrumented by a dummy 'opening clause $=\mathrm{I}$, if yes; $=0$ otherwise', by a dummy 'company agreement $=\mathrm{I}$, if yes; $=0$ otherwise' and by the total numbers of employees.

Source: IAB Establishment Panel, 200I-20I0.

In 2006, in our sample, the average number of employees in firms without a CLP is 124 and that in firms with a CLP is 794. In other words, large firms have a higher propensity to agree to a CLP. Approximately $8 \%$ of all firms have firm-level contracts, and approximately $7 \%$ of all firms have a CLP. Among the latter, $60 \%$ are involved in industry collective bargaining, $22 \%$ have firm-level collective contracts and $28 \%$ have agreed opening clauses, which are a necessary condition in firms with industry-wide collective bargaining for adoption of a CLP.

\section{Investment effects before and during the recession}

Notably, we are mainly interested in the impact of CLPs. Table 2 presents the regression coefficients estimated for different investment equations. We can see that the CLPs have predominately positive but insignificant effects on the firm investment. If location investments are explicitly agreed upon in CLPs, the effect on total investments is significantly positive (Bellmann et al., 2013: Table 7, line 1). In this case, the CLP coefficient is 0.2268 for the period from 2001 to 2009 and 0.1733 for the period from 2001 to 2008 . Among the three investment variables (total investment, reinvestment and net investment) the negative coefficients refer to the net investment only. The latter coefficients are negative without any exceptions and are more often significant.

The separate presentation of Panels A and B in Table 2 is intended to show whether the Great Recession has an important influence on the relationship between CLPs and investment. The real gross domestic product (GDP) began contracting in the third quarter of 2008 in the United States, and by early 2009 was falling at an annualized pace not observed since the 1950s. In Germany, negative growth rates of GDP were observed from the fourth quarter of 2008 to the fourth quarter of 2009 compared with the previous 
year's value. In principle Panels A and B in Table 2 demonstrate a related pattern, albeit estimates broken down by several years are considered - see Table A3. In this case some sharp differences are revealed. The positive effect of CLPs on total investment is evidently lower if the major recession year 2009 is incorporated. The same phenomenon is true if we consider only reinvestment.

Furthermore, an IV estimator is applied and the results can be found on the right hand side of Table 2. The idea is that the adoption of a company-level pact is induced by investments, that the association between the introduction of a CLP and an investment decision is likely interdependent. A low initial level of investment by a firm increases the probability that a CLP will be introduced. An IV instead of an OLS estimator is used to avoid a possible simultaneous bias. As an instrument we employ an opening clause dummy $(\mathrm{OC}=1$, if an opening clause exists; $\mathrm{OC}=0$ otherwise). As already mentioned above, an opening clause means that a firm could deviate from the agreements of an industry-level contract, if some triggering event occurs, e.g. a bad economic situation or strong competitive pressure. We should note that a CLP is often adopted if an opening clause has already existed over a long period of time. However, we do not expect a direct effect on investment due to the existence of an opening clause. Furthermore, a dummy whether a company agreement exists, i.e. the establishment has a firm-level bargaining agreement, and the number of employees are used as additional instruments. The collective agreement dummy is employed because firms with such a regime do not need an opening clause to agree a CLP, but these firms have a higher propensity to adopt a CLP than other firms - see previous subsection and Table A1 in the Appendix. It is easier to install a CLP if a collective agreement exists because it is clear who the negotiating partners are. Otherwise, the employees fear that the employer will dominate the negotiation. The number of employees is incorporated as we expect that large firms are more interested than small firms in CLPs - see previous subsection and Table A1 (Appendix). Clearly, the number of employees has a direct impact on the investment volume. However, a direct effect on the growth rate of the capital stock is at least not obvious.

The LIML instead of the 2SLS estimator is preferred, as we use three instruments. Donald and Newey (2001) have shown that for large numbers of instruments, the LIML should dominate the 2SLS in terms of MSE. Problematically, nearly all instruments may actually be weak instruments or exclusion restrictions may not be fulfilled. However, we find - see Table A1 in the Appendix - that the opening clause dummy, the collective agreement dummy and the number of employees are statistically significant determinants of CLP using probit estimates. Stock-Yogo tests reject the null hypothesis that the instruments are weak and Sargan tests of overidentifying restrictions do not reject the null hypothesis that the instrument set is suitable (Bellmann et al., 2013: 14).

The comparison of the OLS and IV estimates in Table 2 shows some similarities and some differences: the CLP effect on total and replacement investment is insignificant. This is consistent with previous estimates regarding the influence of unions and works councils on investment - see earlier. It seems that CLPs have no effect on replacement and total investment. However, CLPs might stop a firm from facing a negative trend of reinvestment. The effect on net investment is negative and this sign is independent of whether the year of the Great Recession is considered. The existence of a CLP does not prevent the negative effect on firm net investment. Firms that are facing a critical 
economic situation do not solve their problems by expansion, but by modernization. The firms are uncertain about whether the consolidation of employee and employer interests via CLP will be successful. Therefore, firms prefer a strategy of caution with the hope of a long-term recovery. The IV estimates compared with the OLS estimates reveal a stronger tendency to negative net investment effects and to positive reinvestment. In other words, the absolute coefficients of the instrumented estimates are higher than that of non-instrumented estimates. This result is consistent with other studies (e.g. Card, 2001; Machin et al., 2012; Schultz, 2002). The comparison of Panel A and B in Table 2 highlights that the Great Recession reduces the positive CLP effects on reinvestment, while the changes of the negative effects of a CLP on net investment are ambiguous. The success of a CLP is less likely during a crisis.

An examination of the complete estimates in Table A2, columns OLS and IV shows negative short-run (a lagged growth rate of capital stock) and long-run effects (the log of the capital-sales ratio). When the recession year 2009 is excluded, we find the same tendency towards negative short-run and long-run effects. Low investment rates in the past and past under-investment compared to the equilibrium investment based on sales lead to more investment. The coefficients of industry-wide central bargaining (CB), works councils (WOCO) and profit sharing (PS) have the expected signs but the influence is insignificant. In Tables A3 and A4 (Appendix) the results of some robustness checks are presented. As can be seen, the basic outcomes do not vary qualitatively.

\section{Phases of company-level pacts}

Our previous results show that firms with a CLP have higher replacement and lower net investment rates than other firms where only the latter effects are statistically significant. Some possible reasons for this result and empirical hints were discussed in earlier sections. Additionally, we investigate, whether the different investment activities exist between establishments with and without CLPs:

- Induced during the negotiation phase;

- Caused by CLP coming into effect;

- Emerging during the contract period of the CLP;

- Continuing once the CLP has expired.

It is necessary to investigate the effectiveness of CLPs during the different phases. Otherwise, an assessment of investment activity can have negative consequences. Negotiating partners become impatient with investment efforts or the timing of investments may be unsuccessful. In order to test whether the positive investment effect of CLPs is directly due to the adoption of a CLP by a firm or whether investment activities are induced during the contract period of a CLP, the left hand side of Table 3 is presented, where the dummy CLP is substituted by another dummy. This is adopted CLP, such that $\mathrm{CLP}_{i t}=1$, if the CLP is started in firm $\mathrm{i}$ for year $\mathrm{t}$, otherwise $\mathrm{CLP}_{\mathrm{it}}=0$. The adoption induces significantly strong reinvestments. This result exceeds, on average, the investment level by firms with a CLP during the contract period and by firms without CLPs at all. During the contract duration, the elevated investment activity declines as we see in 
Table 3. The investment effects of adoption and expiring of CLPs.

\begin{tabular}{|c|c|c|c|c|c|c|}
\hline & \multicolumn{3}{|c|}{ Adopted CLP } & \multicolumn{3}{|c|}{ Expired CLP } \\
\hline & $N$ & Coef. & SE & $N$ & Coef. & SE \\
\hline \multicolumn{7}{|c|}{ Panel A: 200I-2009 } \\
\hline $\begin{array}{l}\Delta \text { total } \\
\text { investment }\end{array}$ & 21,160 & $0.1910 * *$ & 0.0834 & 1027 & -0.3960 & 0.3641 \\
\hline$\Delta$ reinvestment & 20,568 & $0.2235 * * *$ & 0.0803 & 989 & -0.4429 & 0.3465 \\
\hline$\Delta$ net investment & 20,579 & 0.0014 & 0.0238 & 989 & 0.0474 & 0.2929 \\
\hline \multicolumn{7}{|l|}{ Panel B: $200 \mathrm{I}-2008$} \\
\hline $\begin{array}{l}\Delta \text { total } \\
\text { investment }\end{array}$ & 16,505 & $0.1943 *$ & 0.1188 & 784 & -0.2329 & 0.4610 \\
\hline$\Delta$ reinvestment & 16,035 & $0.1970 *$ & 0.1197 & 755 & -0.3682 & 0.4025 \\
\hline$\Delta$ net investment & 16,044 & 0.0285 & 0.0259 & 755 & 0.0893 & 0.1603 \\
\hline
\end{tabular}

Notes: * significant at the $10 \%$ level; ** significant at the $5 \%$ level; *** significant at the $1 \%$ level. Cluster robust standard errors with respect to the firms are presented. The control variables are change of firm size, bargaining, works council, profit sharing, time and industry dummies. In the left hand side panel, firms who have adopted a CLP in period $t$ are compared with all other firms. In the right hand side panel, firms whose pact has expired in period $t$ are only compared with firms in which a pact still exists.

Source: IAB Establishment Panel, 200I-20I0.

comparison of the analogous estimates in Table 2, although these estimates are not completely comparable. The effect on the net investment rate of a firm is also positive as the result of an adoption of a CLP, in contrast to that of all CLP firms. We should mention that the total investment effect of the adoption of a CLP is not strongly affected by the recession - compare line $\Delta$ total investment in Panel A and B of Table 3.

Overall, CLPs induce positive initial effects on firm investment, but they do not lead to permanent changes in this regard. This impression is strengthened if we look to the right hand side panel of Table 3. Total investment and reinvestment effects are negative - see coefficients in Panel A ( -0.3960 and -0.4429$)$ and in Panel B of Table $3(-0.2329$ and -0.3682 ). The negative effect on reinvestment may be due to the fact that capital stock was renewed during the CLP period and therefore in the following years the firms had less need to reinvest. The capital widening in the post CLP period - cf. line $\Delta$ net investment on the right hand side of Table 3 - demonstrates positive but insignificant spillover effects.

Furthermore, we compare the investment activities of group CLP $=1$ with those of different other groups. This approach allows us to differentiate between investment effects of further phases. We have information on whether,

- An agreement existed in the past and is now discontinued;

- There are currently negotiations under way for such an agreement;

- The efforts to achieve a CLP have failed in the past.

The outcome of the comparisons can be found in Table 4, where firms with different CLP phases are matched with firms that did not have a CLP. In lines (1A), (1B), (2A) and 
Table 4. The investment effects of CLPs under alternative treatment and control groups.

\begin{tabular}{lllll}
\hline Treatment group & Control group & $N$ & \multicolumn{1}{l}{ Coef. } & SE \\
\hline Panel A: 200I-2009 & & & & \\
(IA) CLP & NCLP & 1108 & $0.1154^{* *}$ & 0.0603 \\
(2A) NCLP & NOCLP & 15,463 & $-0.1098^{*}$ & 0.0639 \\
(3A) PCLP & NOCLP & 15,457 & -0.0095 & 0.0624 \\
(4A) FCLP & NOCLP & 15,508 & -0.0956 & 0.0776 \\
Panel B: $200 I-2008$ & & & & \\
(IB) CLP & NCLP & 798 & $0.1301 *$ & 0.0743 \\
(2B) NCLP & NOCLP & 11,749 & -0.0853 & 0.0679 \\
(3B) PCLP & NOCLP & 11,739 & 0.0065 & 0.0737 \\
(4B) FCLP & NOCLP & 11,780 & -0.0598 & 0.0860 \\
\hline
\end{tabular}

Notes: * significant at the $10 \%$ level; ** significant at the $5 \%$ level; *** significant at the $1 \%$ level. Cluster robust standard errors with respect to the firms are presented. Control variables are the same as in Table A2. CLP: with company-level pact.

NCLP: planned company-level pact, ongoing negotiations.

NOCLP: no company-level pact.

PCLP: company-level pact in the past, expired.

FCLP: planned company-level pact, but negotiations failed.

Source: IAB Establishment Panel, 200I-20I0.

(2B), we can see that investment is not higher during the negotiation on a CLP agreement compared with firms with an adopted CLP and with firms with no CLP. Furthermore, investment in firms that are currently negotiating a CLP agreement is lower than in firms with pacts in the past or than in firms in which efforts to achieve an agreement failed in the past. This outcome is not only the case for total investment but also for reinvestment and for net investment. These results are not presented in the tables.

We should note that establishments that had pacts in the past or that have attempted to negotiate pacts invest less than establishments without any pacts during the studied period, including the recession phase 2009 - see lines (3A) and (4A) of Table 4. Although these effects are insignificant, this finding is evidence that investment behaviour is not completely stabilized by CLPs. If CLPs have expired and the firms are affected by a crisis, CLPs reduce firm investment activities. In the pre-recession period - see line (3B) - total investment in establishments with pacts in the past is higher than investment by establishments without any pacts.

\section{Conclusion}

Our estimates reveal positive coefficients of CLPs for both total and replacement investments. If locational investments are explicitly agreed to in CLPs, the effects are significant. Otherwise, the effects are often statistically insignificant. This result is consistent with those of other empirical studies that analyse the correlation between the existence of works councils and investments. The positive coefficients suggest that CLPs induce (replacement) investments in the majority of establishments under normal economic 
conditions. Strong variations in investment behaviours of firms and imprecise standard errors may be responsible for the insignificance of the effects when locational investments are not agreed to. The implied modernization of an establishment's capital stock is driven by reinvestment rather than by net investment. The latter is declining under CLPs, and this result is statistically significant. Generally, firms respond to critical economic situations by investing less, which is especially true with regard to the Great Recession. The contrast between the effects on replacement investments and net investments under company-level pacts demonstrates that CLPs do not successfully contribute to the growth of the firm's capital stock but only contribute to the consolidation and modernization of the capital stock. This is not surprising because CLPs are usually not long-lasting, especially if the CLP is installed during a crisis when the establishment is facing a problem with competitiveness but not a problem related to a lack of capacities. Therefore, growth of the capital stock is not the objective; rather the aim is modernization of the stock.

Our findings are mixed with respect to the level of firm investment during different phases of a CLP. First, we cannot detect any positive increase in investment during the negotiation phase. Second, firm investment behaviour is ambiguous for the duration of a finalized CLP. We find that, after the expiration of a CLP, lower reinvestment and a small increase in net investment occurs. Third, total investment during the phase following the expiration of a CLP is less than it is during the contract phase. Furthermore, with the exception of economic slumps, the total investment for firms with CLPs remains greater than investments for firms that never had CLPs. However, the significantly positive adoption effects of a CLP on reinvestment do not seem permanent. Additionally, the results are strongly affected by the Great Recession. We observe an increase in diminishing or disappearing investments. It is also noted that firm compliance with agreements that are of significant length appears to be lower than that of firms with shorter agreements.

Further research requires data from longer periods where more information regarding financial limitations on investments, on cash flows and on expectations is available. It is of interest to determine whether and why firms are reluctant to invest despite the high profits derived from investments. Are unrealistic ambitious profit aims or negative developments on the financial markets responsible? In 1998, the European Foundation of Living and Working Conditions launched a large international study about the nature and extent of CLPs, including the content of these pacts. A new study should be conducted in the face of an ongoing crisis. Furthermore, empirical investigations should simultaneously analyse the effects on employment and investment and should focus more on the influence of specific measures and the specific mixture of measures in relation to the cyclical development of firm investment. Company-level pacts can improve the competitiveness of an establishment. Nevertheless, permanent CLPs are usually not promising as employees are not willing to accept concessions over a long period without balanced returns. In fact, employees react to the unbalanced returns to their concessions by working at a lower level of productivity or by quitting when other firms supply better labour conditions. Permanent derogations from collective contracts are not useful because such exemptions decrease the incentives for firms to become as profitable as those competitors who fulfil completely the norms of collective bargaining agreements. 
Currently, an empirical comparison between the effects of CLPs on investments as determined in our investigation with other countries is not possible. As the investigations using data from other countries are usually case studies or are focused on determinants of concession bargaining, they do not analyse investment effects under specific company measures. Accordingly, it would be useful if future econometric investigations are extended in a comparable way to other countries. In conjunction with the enormous economic problems, more CLPs may be adopted, especially in South Europe. In these countries the problems cannot be solved by macroeconomic policy measures alone.

\section{Funding}

This research received no specific grant from any funding agency in the public, commercial, or not-for-profit sectors.

\section{References}

Addison J, Schank T, Schnabel C and Wagner J (2007) Do works councils inhibit investment? Industrial and Labor Relations Review 60: 187-203.

Addison J, Schnabel C and Wagner J (1996) German works councils, profits, and innovation. Kyklos 49: 555-582.

Addison J, Schnabel C and Wagner J (2001) Works councils in Germany: Their effects on firm performance. Oxford Economic Papers 53: 659-694.

Askildsen JE, Jirjahn U and Smith SC (2006) Works councils and environmental investment: Theory and evidence from German Panel Data. Journal of Economic Behavior and Organization 60: 346-372.

Bell LA (1995) The union wage concessions in the 1980s: The importance of firm-specific factors. Industrial and Labor Relations Review 48: 258-275.

Bellmann L and Gerner HD (2012a) Company-level pacts for employment in the global crisis 2008/2009: First evidence from representative German establishment-level panel data. The International Journal of Human Resource Management 23: 3375-3396.

Bellmann L and Gerner HD (2012b) Continuous training and company-level pacts for employment in Germany. Journal of Economics and Statistics 232: 98-115.

Bellmann L, Gerlach K and Meyer W (2008) Company-level pacts for employment. Journal of Economics and Statistics 228: 533-553.

Bellmann L, Gerner HD and Hübler O (2013) Investment under company level pacts. IZA DP No. 7195, Bonn.

Blanchflower D (1991) The economic effects of profit sharing in Great Britain. International Journal of Manpower 12: 3-9.

Bogedan C, Brehmer W and Seifert H (2011) Wie krisenfest sind betriebliche Bündnisse zur Beschäftigungssicherung? WSI Mitteilungen 64: 51-59.

Bronars SG and Deere DR (1993) Unionization, incomplete contracting, and capital investment. Journal of Business 66: 117-132.

Cappelli P (1985) Plant-level concession bargaining. Industrial and Labor Relations Review 39: 90-104.

Card D (2001) Estimating the return to schooling: Progress on some persistent econometric problems. Econometrica 69: 1127-1160.

Card D, Devicienti F and Maida A (2011) Rent-sharing, hold-up, and wages: Evidence from matched panel data. IZA DP No. 6086. 
Donald SG and Newey WK (2001) Choosing the number of instruments. Econometrica 69: 1161-1191. Eaton J and Verma A (2006) Does 'fighting back' make a difference? The case of the Canadian Auto Workers Union. Journal of Labor Research 27: 187-212.

Ellguth P and Kohaut S (2008) Ein Bund fürs Überleben? Betriebliche Vereinbarungen zur Beschäftigungs- und Standortsicherung. Industrielle Beziehungen 15: 209-232.

Fan J and Gijbels I (1996) Local Polynomial Modelling and its Applications. London: Chapman and Hall.

Freeman RB and Lazear EP (1995) An economic analysis of works councils. In: Rogers J and Streeck W (eds) Works Councils: Consultation, Representation and Cooperation in Industrial Relations. Chicago: University of Chicago Press, pp. 27-52.

Freyssinet J and Seifert H (2001) Negotiating Collective Agreements on Employment and Competitiveness. Luxembourg: Office for Official Publications of the European Communities.

Guertzgen N (2010) Rent-sharing and collective wage contracts: Evidence from German establishment-level data. Applied Economics 42: 2835-2854.

Hübler O (2003) Zum Einfluss des Betriebsrates in mittelgroßen Unternehmen auf Investitionen, Löhne, Produktivität und Renten - Empirische Befunde. In: Goldschmidt N (ed.) WunderWirtschaftsWelt.- The New Economy und ihre Herausforderungen. Baden-Baden: Nomos Verlagsgesellschaft, pp. 77-94.

Hübler O (2005) Sind betriebliche Bündnisse für Arbeit erfolgreich? Journal of Economics and Statistics 225: 630-652.

Hübler O (2006) Zum Einfluss betrieblicher Bündnisse auf die wirtschaftliche Lage der Unternehmen. Review of Economics 57: 121-146.

Jirjahn U (1998) Effizienzwirkungen von Erfolgsbeteiligung und Partizipation. Campus: FrankfurtNew York.

Kruse DL (1993) Profit Sharing: Does it Make a Difference? Michigan: Upjohn Institute for Employment Research.

Lesch H (2008) Betriebliche Bündnisse für Arbeit in der Metall- und Elektro-Industrie. IW Trends 4/2008.

Machin S, Marie O and Vujić S (2012) Youth crime and education expansion. German Economic Review 13: 366-384.

Mairesse J, Hall BH and Mulkay B (1999) Firm-level investment in France and the United States: An exploration of what we have learned in twenty years. Annales d'Economie et de Statistique 55-56: 27-67.

Massa-Wirth H and Seifert H (2004) Betriebliche Bündnisse nur mit begrenzter Reichweite. WSIMitteilungen 57: 246-254.

Massa-Wirth H and Seifert H (2005) German pacts for employment and competitiveness: Concessionary bargaining as a reaction to globalisation and European integration? Transfer: European Review of Labour and Research 11: 26-44.

Mueller S (2008) Capital stock approximation using firm level panel data. Journal of Economics and Statistics 228: 357-371.

Nienhüser W and Hoßfeld H (2010a) Vertrauen und Verbetrieblichungsneigung von Managern und Betriebsräten. Ergebnisse einer empirischen Erhebung - Teil 1. Sozialer Fortschritt 59: 219-225.

Nienhüser W and Hoßfeld H (2010b) Vertrauen und Verbetrieblichungsneigung von Managern und Betriebsräten. Ergebnisse einer empirischen Erhebung - Teil 2. Sozialer Fortschritt 59: 227-234.

Schultz TP (2002) Wage gains associated with height as a form of health human capital. American Economic Review, Paper and Proceedings 92: 349-353. 
Seifert H and Massa-Wirth H (2005) Pacts for employment and competitiveness. Industrial Relations Journal 36: 217-240.

Sisson K (2001) Pacts for employment and competitiveness: An opportunity to reflect on the role and practice of collective bargaining. Transfer: European Review of Labour and Research 7: $600-615$.

Sisson K and Martin Artiles A (2000) Handling Restructuring: A Study of Collective Agreements Dealing with Employment and Competitiveness. Luxembourg: Office for the Official Publications of the European Communities.

Sisson K, Freyssinet J, Krieger H et al. (1999) Pacts for Employment and Competitiveness: Concepts and Issues. Dublin: European Foundation for the Improvement of Living and Working Conditions.

Spence M and Hlatshwayo S (2011) The evolving structure of the American economy and the employment challenge, Working Paper.

Zagelmeyer S (2000) Getting in gear for global competition: Pacts on employment and competitiveness in the EU automobile industry. Transfer: European Review of Labour and Research 7: $650-656$.

Zagelmeyer S (2010) Company-level bargaining in times of crisis: The case of Germany. Working Paper No. 9. International Labour Office, Industrial and Employment Department, Geneva.

\section{Author biographies}

Lutz Bellmann is a Professor of Labour Economics at the University of Erlangen-Nuremberg and head of the department Establishments and Employment at the Institute for Employment Research in Nuremberg. His main research interests are industrial relations, firm-level employment adjustments and firm-provided training. Recent publications in these fields include: 'Foreign-owned plants and job security', Review of World Economics 148(1) (2012): 89-117 (with M Andrews, T Schank and R Upward); 'Resisting the crisis: Short-time work in Germany', International Journal of Manpower 33(8) (2012): 877-900 (with A Crimmann and F Wießner); and 'Profit sharing and employment stability', Schmalenbach Business Review 62(1) (2010): 73-92 (with I Möller).

Hans-Dieter Gerner is a Senior Researcher at the Institute for Employment Research (IAB) Nuremberg, Germany. His main research interests are working time, wages and industrial relations. One recent publication in this field is: 'Wage effects of opening clauses and works councils: The German case', Economic and Industrial Democracy (2012) (with P Ellguth and J Stegmaier).

Olaf Hübler is a Professor for Empirical Economics and Applied Econometrics at the Leibniz University of Hannover, retired since 2011. His research interests include applied econometrics and labour economics with special interest in micro-econometrics, panel data methods in non-linear models, wages, profit sharing and other incentives, gender wage gaps, mobility, working time and evaluation of social programmes and in-plant alliances. Three recent publications are: 'Are tall people less risk averse than others?', Journal of Applied Social Science Studies 133 (2013): 23-42; 'Unobserved individual and firm heterogeneity in wage and job duration functions: Evidence from German linked employer-employee data', German Economic Review 12 (2011): 469-489 (with T Cornelißen); and 'Do women manage smaller funds?', Scottish Journal of Political Economy 58 (2011): 107-126 (with L Menkhoff). 


\section{Appendix}

Table Al. Probit estimation of CLP.

\begin{tabular}{|c|c|c|c|c|}
\hline & \multicolumn{2}{|c|}{ Panel A: 200I-2009 } & \multicolumn{2}{|c|}{ Panel B: 200I-2008 } \\
\hline & Coef. & Robust SE & Coef. & Robust SE \\
\hline Opening clause & $0.3219 * * *$ & 0.0458 & $0.3308 * * *$ & 0.0529 \\
\hline Company agreement & $0.3366 * * *$ & 0.0542 & $0.3748 * * *$ & 0.0619 \\
\hline Number of employees/I000 & $0.0565 * *$ & 0.0225 & $0.0443 * *$ & 0.0201 \\
\hline $\begin{array}{l}\text { Lagged growth rate of capital } \\
\text { stock }\end{array}$ & $-0.0415^{* *}$ & 0.0207 & $-0.0425 *$ & 0.0249 \\
\hline Growth in sales & 0.0465 & 0.0560 & 0.0628 & 0.0616 \\
\hline Lagged growth in sales & $-0.2679 * * *$ & 0.0590 & -0.0498 & 0.0828 \\
\hline Log of the capital-sales ratio & 0.0161 & 0.0159 & 0.0158 & 0.0186 \\
\hline Log of sales & $0.1382 * * *$ & 0.0147 & $0.1298 * * *$ & 0.0168 \\
\hline Construction & $-0.3000 * * *$ & 0.0845 & $-0.3347 * * *$ & 0.0992 \\
\hline Trade & $-0.3004 * * *$ & 0.0731 & $-0.2874 * * *$ & 0.0863 \\
\hline Traffic & -0.0318 & 0.0883 & -0.0148 & 0.1005 \\
\hline Company services & $-0.2719 * * *$ & 0.0779 & $-0.3500 * * *$ & 0.0985 \\
\hline Other services & $-0.1510 * *$ & 0.0772 & $-0.2124 * *$ & 0.0968 \\
\hline Central bargaining & $0.2288 * * *$ & 0.0443 & $0.2956 * * *$ & 0.0606 \\
\hline Works council & $0.7995 * * *$ & 0.0566 & $0.8221^{* * *}$ & 0.0659 \\
\hline Profit sharing & $-0.2228 * * *$ & 0.0443 & $-0.1849 * * *$ & 0.0526 \\
\hline Const. & $-3.9635 * * *$ & 0.2548 & $-3.9785 * * *$ & 0.2974 \\
\hline Number of observations & 16,462 & & 12,557 & \\
\hline Wald $\operatorname{chi}^{2}(15)$ & 1821.46 & & 1296.95 & \\
\hline Prob $>$ chi $^{2}$ & 0.0000 & & 0.0000 & \\
\hline Pseudo $R^{2}$ & 0.3380 & & 0.3472 & \\
\hline
\end{tabular}

Source: IAB Establishment Panel, 200I-20I0. 
Table A2. Effects of CLPs on total investment (the growth rate of capital stock) - standard model 200I-2009.

\begin{tabular}{|c|c|c|c|c|}
\hline & \multicolumn{2}{|l|}{ OLS } & \multicolumn{2}{|l|}{ IV } \\
\hline & Coef. & SE & Coef. & SE \\
\hline Company-level pact (CLP) & 0.0424 & 0.0614 & 0.1341 & 0.3618 \\
\hline Number of employees/1000 & $0.1150 *$ & 0.0686 & & \\
\hline Lagged GRC & $-0.0117^{* * *}$ & $0.004 I$ & $-0.0123^{* * *}$ & 0.0041 \\
\hline Growth in sales & 0.0682 & $0.047 \mid$ & $0.0633^{* *}$ & 0.0361 \\
\hline Lagged growth in sales & -0.0557 & 0.0401 & -0.0590 & 0.0374 \\
\hline Log of the capital-sales ratio & $-0.2880 * * *$ & 0.0267 & $-0.2209 * * *$ & 0.0106 \\
\hline Log of sales & $-0.0455^{* * *}$ & 0.0124 & $-0.0320 * * *$ & 0.0117 \\
\hline Construction & $-0.206 I^{* * *}$ & 0.0549 & $-0.1706 * * *$ & 0.0475 \\
\hline Trade & $-0.2669 * * *$ & 0.0678 & $-0.1570^{* * * *}$ & 0.0437 \\
\hline Traffic & 0.0973 & 0.0827 & 0.0537 & 0.0725 \\
\hline Telecommunications & 0.0532 & 0.0796 & 0.0420 & 0.6080 \\
\hline Company services & $-0.1690 * * *$ & 0.0470 & $-0.1205^{* * * *}$ & 0.0431 \\
\hline Other services & -0.0696 & 0.0522 & -0.0109 & 0.0470 \\
\hline Central bargaining & -0.0194 & 0.0366 & -0.0015 & 0.0327 \\
\hline Works council & 0.0307 & 0.0531 & 0.0005 & 0.0632 \\
\hline Profit sharing & -0.0332 & 0.0425 & -0.0163 & 0.0395 \\
\hline Const. & $0.4188^{* *}$ & 0.1974 & 0.3110 & 0.1824 \\
\hline Number of observations & 16,599 & & 16,470 & \\
\hline$R^{2}$ & 0.0363 & & 0.0282 & \\
\hline
\end{tabular}

Notes: * significant at the $10 \%$ level; ** significant at the $5 \%$ level; *** significant at the $1 \%$ level. Cluster robust standard errors with respect to the firms are presented. GRC is the growth rate of the capital stock. In the IV estimates CLP is instrumented by a dummy 'opening clause $(O C)=1$, if yes; = 0 otherwise', by a dummy 'company agreement $(C A)=I$, if yes; $=0$ otherwise' and by the total numbers of employees $(\mathrm{NoE})$. Source: IAB Establishment Panel, 200I-20I0.

Table A3. Estimates of the standard model for alternative periods.

\begin{tabular}{llllll}
\hline Period & $N$ & $\begin{array}{l}\text { OLS } \\
\text { coef. }\end{array}$ & SE & \multicolumn{1}{l}{$\begin{array}{l}\text { Tobit } \\
\text { coef. }\end{array}$} & SE \\
\hline $2001-2007$ & 8784 & 0.0946 & 0.1079 & 0.0849 & 0.1166 \\
2006 & 3016 & 0.2799 & 0.2669 & 0.2041 & 0.2752 \\
2007 & 3344 & 0.0421 & 0.0693 & 0.0403 & 0.1028 \\
2008 & 3765 & $0.1094^{*}$ & 0.0586 & 0.0012 & 0.0994 \\
2009 & 3929 & -0.1085 & 0.0765 & $-0.1895^{*}$ & 0.1134 \\
\hline
\end{tabular}

Notes: * significant at the $10 \%$ level; ** significant at the $5 \%$ level; *** significant at the $1 \%$ level. The coefficient of the CLP dummy variable on total investment and cluster robust standard errors with respect to the firms are presented. The same control variables are incorporated as in Appendix Table A2.

Source: IAB Establishment Panel, 200I-2010. 
Table A4. Robustness checks of the standard model.

\begin{tabular}{|c|c|c|c|c|c|c|}
\hline & \multicolumn{3}{|c|}{ Panel A: 200I-2009 } & \multicolumn{3}{|c|}{ Panel B: $200 \mathrm{I}-2008$} \\
\hline & $N$ & Coef. & SE & $N$ & Coef. & SE \\
\hline $\begin{array}{l}\text { (I) Parsimonious } \\
\text { specification }^{\mathrm{a}}\end{array}$ & 19,466 & 0.0552 & $0.054 I$ & 15,492 & 0.0855 & 0.0575 \\
\hline (2) Mairesse approach ${ }^{b}$ & 19,469 & $0.1445^{*}$ & 0.0810 & 15,485 & 0.1956 & 0.1017 \\
\hline (3) $\operatorname{ADL}(I, I)^{c}$ & $19,50 \mid$ & 0.0190 & 0.0568 & 15,422 & 0.0575 & 0.0609 \\
\hline (4) Extended specification ${ }^{d}$ & 19,417 & 0.0856 & 0.0854 & 15,439 & 0.1433 & 0.1072 \\
\hline (5) Hausman-Taylor & 15,994 & 0.0008 & 0.0114 & 12,174 & 0.0123 & 0.0153 \\
\hline
\end{tabular}

Notes: * significant at the $10 \%$ level; ** significant at the $5 \%$ level; *** significant at the $1 \%$ level. The coefficient of the CLP dummy variable on total investment and cluster robust standard errors with respect to the firms are presented.

aStandard model without central bargaining, works council and profit sharing as control variables.

bRegressors: lagged growth rate of capital stock, growth in sales, lagged growth in sales, log of the capitaloutput ratio, log of sales and CLP dummy.

'Autoregressive distributed lag model: $\operatorname{ADL}(I, I)$ instead of $\operatorname{ADL}(2,2)$ as in the other specifications. With time dummies as additional control variables to the standard mode.

eHausman-Taylor panel estimator.

Source: IAB Establishment Panel, 200I-20I0. 